\title{
JMAWAbdi
}

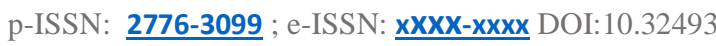

Jurnal Ilmiah Mahasiswa Mengabdi (JIMA WAbdi)

Volume 1 Nomor 1, April $2021(17$ - 20)

http://openjournal.unpam.ac.id/index.php/JMAb/index

\section{Pelatihan Kesadaran Menabung Sejak Dini Bagi Kelompok Belajar Sanggar Ceria, Desa Karang Tengah}

\author{
Adha Nisa Nurhikmah ${ }^{1}$, Muhammad Farhan², Siva Nurhaliza ${ }^{3}$, Sonia Isabela $^{4}$, Vina Priyanti $^{5}$, \\ Nugroho Widhi Pratomo ${ }^{6 *}$ \\ 1,2,3,4,5 Mahasiswa S-1 Akuntansi, Universitas Pamulang; annhnisa@gmail.com ${ }^{1}$ \\ ${ }^{6}$ Fakultas Ekonomi, Prodi Akuntansi, Universitas Pamulang; dosen01404@unpam.ac.id*
}

Received 04 April 2021| Revised 15 April 2021 | Accepted 22 April 2021

*Korespondensi Penulis

\begin{abstract}
Abstrak
Sesuai dengan Tri Dharma Perguruan Tinggi salah satunya pengabdian kepada masyarakat (PKM) maka tanggung jawab seorang mahasiswa setelah menyelesaikan tugas belajar di kampus adalah mentransfer, mentransformasikan, dan mengaplikasikan ilmu pengetahuan dari dalam kampus kepada masyarakat. Oleh karena itu, untuk merealisasikan hal tersebut, melalui kegiatan Pengabdian Mahasiswa Kepada Masyarakat (PMKM), maka Mahasiswa Universitas Pamulang berinisiatif mengusung kegiatan PMKM dengan tema Pelatihan Kesadaran Menabung Sejak Dini. Kegiatan pengabdian ini ditujukan kepada masyarakat terutama anak-anak yang membutuhkan pengetahuan lebih mengenai kesadaran menabung serta tidak lupa juga menyampaikan mengenai pentingnya kesadaran menjaga protocol kesehatan pada masa pandemi saat ini.
\end{abstract}

Kata Kunci : PMKM; Menabung; Kesehatan; Masyarakat

\section{Abstract}

In accordance with the Tri Dharma of Higher Education, one of which is community service (PKM), the responsibility of a student after completing a study assignment on campus is to transfer, transform, and apply knowledge from within the campus to the community. Therefore, to realize this, through the Student Service to the Community (PMKM), Pamulang University Students took the initiative to carry out PMKM activities with the theme Early Saving Awareness Training. This service activity is aimed at the community, especially children who need more knowledge about the awareness of saving and do not forget to also convey the importance of awareness of maintaining health protocols during the current pandemic.

Keywords : PMKM; Saving; Health; Community

\section{PENDAHULAN}

Kegiatan Pengabdian masyarakat oleh mahasiswa ini sebagai bentuk tanggung jawab seorang mahasiswa untuk turut terlibat membantu memecahkan persoalan yang dihadapi oleh masyarakat. Kegiatan Pengabdian masyarakat oleh mahasiswa dapat diartikan sebagai interaksi dinamis antara kelompok masyarakat dan Mahasiswa untuk sama-sama menghadapi beragam tantangan seperti; mengajak perbaikan kehidupan sosial ekonomi, pendidikan, serta mengajak masyarakat untuk peduli pentingnya kesehatan.

Sesuai dengan Tri Dharma Perguruan Tinggi salah satunya pengabdian Mahasiswa kepada masyarakat (PMKM) maka tanggung jawab seorang mahasiswa setelah menyelesaikan tugas belajar di kampus adalah mentransfer, mentransformasikan, dan mengaplikasikan ilmu pengetahuan dari dalam kampus kepada masyarakat. Dalam kegiatan ini, Mahasiswa melakukan pendekatan kepada masyarakat 
untuk tujuan menciptakan sesuatu yang baik dan bermanfaat. Program ini bisa terwujud dengan adanya dukungan dari Dosen, Mahasiswa, serta masyarakat dalam bentuk penguatan partisipasi rakyat dalam proses kegiatan pengabdian ini.

Oleh karena itu, untuk merealisasikan hal tersebut, melalui kegiatan Pengabdian Mahasiswa Kepada Masyarakat (PMKM), maka Mahasiswa Universitas Pamulang berinisiatif mengusung kegiatan PMKM dengan tema Pelatihan Kesadaran Menabung Sejak Dini. Kegiatan pengabdian ini ditujukan kepada masyarakat terutama anak-anak yang membutuhkan pengetahuan lebih mengenai kesadaran menabung serta tidak lupa juga menyampaikan mengenai pentingnya kesadaran menjaga protocol kesehatan pada masa pandemi saat ini.

Dapat dilihat dari waktu ke waktu pelaksanaan kegiatan pengabdian kepada masyarakat telah mendapatkan respons positif dari masyarakat. Respons ini dianggap sebagai sebuah tantangan untuk meningkatkan kegiatan menjadi lebih baik lagi. Banyak masukan baik dari masyarakat maupun lembaga pemerintah bahwa pelaksanaan pengabdian masyarakat dapat dirasakan langsung manfaatnya.

Kegiatan ini dapat menjadi wujud nyata dari partisipasi konkret mahasiswa dalam melakukan pendampinmgan terhadap masyarakat dalam mengatasi problem sosial pada umumnya, lebih-lebih problem sosial pendidikan anak sejak dini pada masa pandemi sekarang ini.

\section{METODE}

\section{Teknik dan Cara Pelaksanaan}

1. Observasi

Observasi atau pengamatan langsung dilakukan untuk mengetahui kondisi sasaran dengan mengamati Sanggar Ceria dan kegiatan yang dilaksanakan nya.

2. Wawancara

Wawancara dilakukan untuk mengetahui kondisi faktual yang lebih detail dengan cara berbincang dengan Ketua RW, Ketua
RT serta Ketua Sanggar Ceria dan KakakKakak Pembina Sanggar Ceria.

3. Konsultasi

Tim berkonsultasi dengan dosen pembimbing dalam penyusunan acara, beserta kondisi yang terjadi. Tim juga berkonsultasi dengan Ketua Sanggar Ceria dalam penyesuaian kegiatan, jadwal, dan materi yang disampaikan.

4. Metode pelatihan

a. Sesi game dilakukan dengan memberikan pertanyaan pertanyaan dengan di selingi permainan guna mengukur kemampuan atau pengetahuan peserta. Jenis pertanyaan dikategorikan ke dalam;

1) Edukasi tentang ilmu pengetahuan sejarah;

2) Edukasi tentang manfaat menabung;

3) Edukasi tentang cara cuci tangan yang baik dan benar;

4) Edukasi mengenai lagu daerah ;

5) Edukasi mengingat dan menghafal jenis-jenis warna.

b. Ceramah interaktif dilakukan saat pemberian materi pengenalan untuk memberikan dasar pengetahuan sebelum praktik langsung. Pengenalan materi juga disertai contoh beberapa kasus dalam kehidupan sehari-hari dalam menabung untuk memberikan gambaran yang lebih jelas kepada anak-anak di Sanggar Ceria.

c. Praktik langsung dilakukan salah satu peserta yang maju ke depan dalam mempraktikkan cara menabung secara langsung kepada peserta yang lain menggunakan celengan yang sudah tersedia.

d. Memberikan materi dengan cara story telling bertemakan "Aku suka menabung" agar anak-anak di Sanggar Ceria dapat mudah mengingat dan lebih fun.

e. Evaluasi dilakukan dengan meminta peserta mengingat materi apa saja yang sudah di jelaskan sebelumnya dan 
meminta peserta untuk mempraktikkan kembali untuk hal menabung serta kebersihan dalam mencuci tangan. Hal ini dilakukan untuk mengetahui keterampilan mengingat para peserta.

\section{Metode penilaian}

Metode penilaian perilaku dilakukan melalui hasil pre test dan post test, evaluasi/tugas akhir, dan pemantauan dari dosen pembimbing dan panitia pelaksana kegiatan PKM

\section{Tahapan Pelaksanaan}

Tabel 1. Tahapan Pelaksanakaan PKM

\begin{tabular}{clc}
\hline \multicolumn{1}{c}{ Tanggal } & \multicolumn{1}{c}{ Kegiatan } & Waktu \\
\hline 21 Febuari & $\begin{array}{l}\text { Rapat pertama } \\
\text { bersama panitia } \\
\text { pelaksana }\end{array}$ & \\
& 10:00-15:00 \\
\hline 11 Maret 2021 & Observasi & $08: 40-11: 00$ \\
\hline 11 Maret 2021 & Wawancara & 11:15-12:10 \\
\hline 14 Maret 2021 & Konsultasi & 07:00-09:00 \\
\hline 14 Maret 2021 & Persiapan & - \\
& Administrasi & \\
\hline 14 Maret 2021 & Rapat kedua & $10: 00-17: 00$ \\
& berssama Panitia & \\
& Pelaksana & \\
\hline 27 Maret 2021 & Persiapan & 13:00-14:00 \\
& perlengkapan & \\
& Alat dan bahan & \\
\hline
\end{tabular}

\section{Sasaran}

Sasaran dalam pengabdian mahasiswa kepada masyarakat ini ialah anak anak karena maksud kegiatan sosialisasi pentingnya menabung sejak dini adalah untuk memberikan pemahaman kepada generasi muda bahwa menabung sangat bermanfaat bagi masa depan. Pemberian celengan dilakukan untuk memberikan motivasi yang lebih bagi siswa untuk menabung., kegiatan ini akan memberikan gambaran secara umum tentang seberapa penting mengelola keuangan sejak usia dini kepada anak anak di desa Karang tengah sekaligus memberikan pemahaman kepada mereka tentang pentingnya mengelola keuangan sejak dini. Termasuk juga mengenai pengambilan keputusan dalam membelanjakan uang yang mereka miliki. Gerakan menabung sejak dini juga bermaksud untuk mendorong dan menanamkan budaya hemat kepada siswa Budaya ini akan memberikan gambaran kebiasan dalam mengelola uang saku sejak usia dini sehingga diharapkan kelak di masa yang akan datang akan menjadi pribadi yang tidak konsumtif serta mampu mengelola pendapatan yang dimiliki..

\section{HASIL DAN PEMBAHASAN}

Kegiatan pelaksanaan ini berjalan dengan sangat lancar antusiasme para anakanak di Sanggar Ceria sangat luar biasa, para peserta kegiatan datang setengah jam sebelum acara dimulai.

Identifikasi ketercapaian ditinjau dari kegiatan pelaksanaan :

Terbentuknya masyarakat yang memberdayakan lingkungan sekitar. Setelah terlaksananya penyuluhan dan pelatihan. Peserta didik Sanggar Ceria melakukan cara menabung dengan tepat dan cara mencuci tangan dengan baik dan benar, serta membuang sampah ke tempatnya, agar lingkungan lebih bersih.

Terbentuknya anak-anak yang terampil dalam inovatif, dan kreatif. Selain itu, Kegiatan Pengabdian Kepada Masyarakat ini memberikan keuntungan bagi anak-anak maupun masyarakat yang tinggal di Kp.Pabuaran Rt.002/Rw.002 Desa Karang Tengah Kecamatan Pagedangan Kabupaten Tangerang untuk disiplin dalam menabung, disiplin dalam waktu dan dapat menghargai uang yang ada serta memanfaatkannya dengan sebaik mungkin. Serta dapat memberikan edukasi yang sangat penting tentang persoalan kebersihan sekitar.

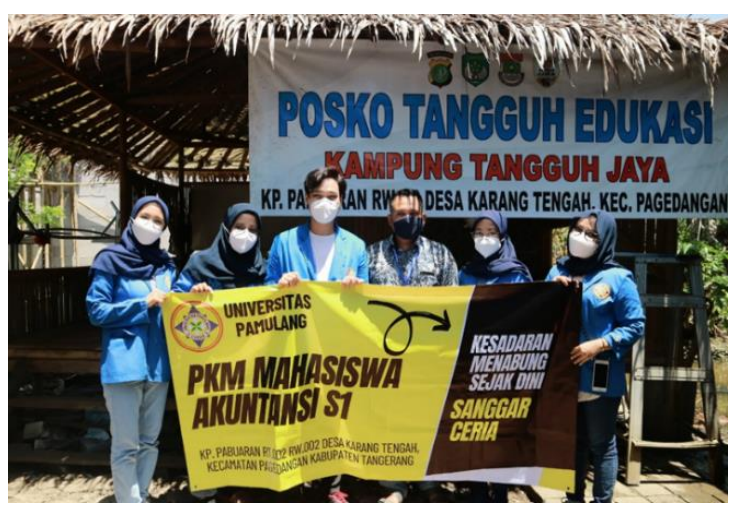

Gambar 1: Panitia PMKM 


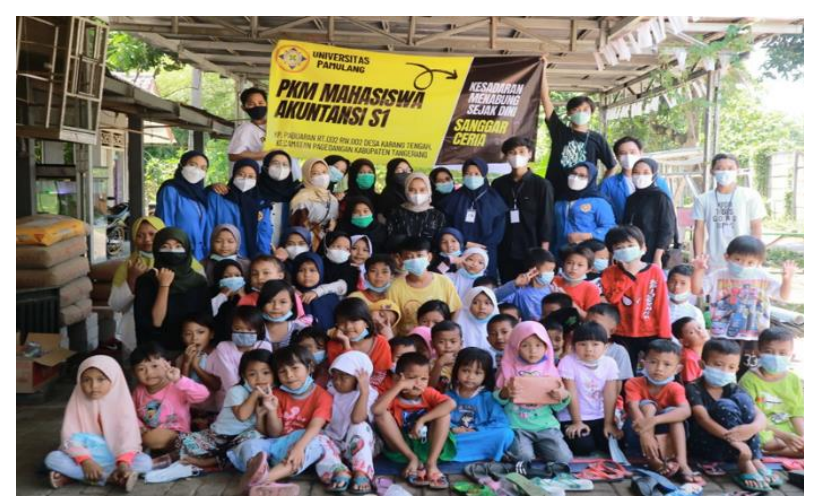

Gambar 2. Kegiatan PMKM bersama Peserta

\section{SIMPULAN}

\section{Kesimpulan}

Dari hasil evaluasi serta temuan-temuan yang kami peroleh selama pelaksanaan kegiatan pengabdian masyarakat ini, dapat kami simpulkan bahwa program pengabdian masyartakat sebagai salah satu wujud dari pelaksanaan tri dharma perguruan tinggi ini telah mampu memberikan manfaat masyarakat khususnya anak-anak di Sanggar Ceria Kampung Pabuaran, Desa Karang Tengah yang menjadi sasaran kegiatan pengabdian ini.

Bentuk pelatihan seperti ini merupakan bentuk yang efektif untuk memberikan penyegaran dan wawasan baru bagi masyarakat khusunya anak-anak di bidang akuntansi berupa kesadaran menabung sejak dini di luar proses pembelajaran yang diterima di sekolah, dan dalam pelaksanaan Program Tridharma Perguruan Tinggi ini, yaitu pelatihan kesadaran menabung sejak dini dan kesadaran menjaga protokol kesehatan pada masa pandemi, tidak ada kendala yang menghambat selama proses pelaksanaan kegiatan serta hasil penyampaian materinya cukup baik dan dapat diterima

\section{Saran}

Sesuai dengan hasil evaluasi yang telah dilakukan, kami berharap kegiatan ini bisa dilaksanakan juga di daerah lainnya, sehingga program-program pegabdian masyarakat seperti ini bisa dilakukan dengan jangka waktu pelaksanaan yang lebih lama agar Dapat dilakukan kegiatan pengabdian lebih lanjut dengan materi yang lebih advance, mengingat sulitnya transfer ketrampilan dalam waktu yang relatif sempit. Serta diperlukan dana yang lebih besar agar hasilnya lebih optimal.

\section{Ucapan Terima Kasih}

Kami selaku pelaksana kegiatan PMKM mengucapkan terima kasih kepada Dosen Pembimbing kami Bapak Nugroho Widhi Pratomo, S.S., M.Pd atas bimbingan nya. Dan terimakasih atas antusias masyarakat Desa Karang Tengah yang telah mendukung kegiatan kami terutama kepada Bapak RT/RW setempat, Ketua Karang Taruna, Ketua Sanggar Ceria, Para Pembina Sanggar Ceria, dan adik-adik Sanggar Ceria. Semoga kegiatan PMKM ini dapat bermanfaat dan mengedukasi masyarakat setempat.

\section{DAFTAR PUSTAKA}

Panduan Penelitian dan Pengabdian Masyarakat Edisi X 2016, DP2M Dikti Jakarta.

Budisantoso, Indrasto \& Gunanto. 2010. Cara Gampang Mengelola Keuangan Pribadi dan Keluarga. Jakarta: PT Gramedia.

Sukardi \& Anwari. (1984). Manfaat menabung dalam tabanas dan taska. Jakarta:Balai Aksara.

Muara, Dayah ( 2015, Agustus) menabung sejak dini. http://unsyiah.ac.id

Marlina, N., \& Iskandar, D. (2019). Gerakan Menabung Sejak Dini di Rowosari. Jurnal Pengabdian Vokasi, 01 (01), 2732. 